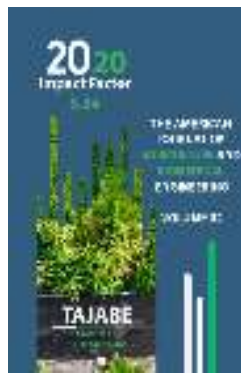

Journal Website: http://usajournalshub.c om/index,php/tajabe

Copyright: Original content from this work may be used under the terms of the creative commons attributes 4.0 licence.

\section{Mechanical Composition Of Gypsum Virgin Land And Irrigated Soils Zarbdar District Of Jizzakh Region}

\author{
Makhkamova Dilafruz Yuldashevna \\ Doctor Of Philosophy In Biological Sciences (PhD), National University Of Uzbekistan Named \\ After Mirzo Ulugbek, Uzbekistan
}

\title{
ABSTRACT
}

The article presents in detail the mechanical composition of gypsum-sierozem, meadow-sierozem, sierozem-meadow, meadow, meadow-swamp soils and saline soils of different levels in the Zarbdor district of the Jizzakh region. Based on the data obtained, it has been given that, in terms of the amount of coarse dust and fine sand fraction, the soils of the region are dominated by medium, heavy and light sands, sometimes shown to ease up to scattered sand.

\section{KEYWORDS}

Irrigated soil, virgin land soil, mechanical composition, coarse dust, medium dust, fine dust, sand fractions, particles.

\section{INTRODUCTION}

The mechanical composition of soils is of enormous significant for soil formation and the use of soil for agricultural purposes, especially in an arid zone. Almost all soil properties, including porosity, water properties, thermal properties, soil-to-air ratio, structure, chemical 
composition, absorption properties, biological activity and fertility, depend on its mechanical composition. The mechanical composition of the soil can largely determine the level of moisture that can be used in the composition of the soil and the amount of nutrients absorbed by the plants. In order to know the components that determine soil fertility and to develop a system of measures to increase fertility, it is necessary to correctly determine the mechanical composition of the soil.

The mechanical composition of the soil significantly affects the water-physical, physico-mechanical, air, thermal properties, conditions of oxidation-reduction processes in the soil, absorption properties, accumulation of humus in the soil, as well as the accumulation of ash elements and nitrogen.

\section{MAIN PART}

The analysis of the mechanical composition of the soils was carried out by the pipette method, based on the treatment of a prototype soil with sodium pyrophosphate, the studied soils were very diverse in texture, consisting mainly of medium sands, light sands, heavy sandy loams and sandy loams. soils are also found. The lithological section has a sharply layered character.

The objects of study were noted to be part of the western part of the Lomakino plateau of the foothills of the Turkestan ridge. Here are two geomorphological - landscape; The upper part is divided into the watershed area (slope of 6-8 $\mathrm{m}$ in height) and the valley part (streams with a height amplitude of $3 \mathrm{~m}$ ).

RESULTS AND DISCUSSION
In the lyoss layers of the slope, the reserve is formed of typical sierozem soil (6 sections), as well as sierozem-meadow soils (sections 7, 9, 1, $11,3,4)$, meadow soils (sections $8,12,5,2,10$ ), these soils have a light to moderate mechanical composition.

The soils of the river valleys are formed on the basis of proluvial-delluvial soils. In different parts of the slopes of the slopes there are meadow-sierozem, sierozem-grass and meadow soils, as well as these soils are partially accumulated by leaching or, conversely, washed away by erosion processes.

There are also meadow-sierozem soils along the steep slopes, along with meadow and saline soils. These soils are characterized by the condition of the protruding rocks and their belonging to different constituent elements of the macro- and microrelief. These soils have a relatively more homogeneous characterization in terms of mechanical composition (sections 1 , $11,3,10)$, as well as on the basis of the arrival of a series of light -, medium - and heavy clay ( 8,9 , 7 sections), layers (sections 2, 12, 4, 5). From the given data it can be seen that the virgin land soils under study are mainly composed of medium, light clayey, sandy, strata. The sequence of these layers, consisting of porous sands, light, medium clays, is sufficiently clear in the whole two-meter layer of the soil subgrade.

It is well-of in coarse dust fractions (particle size $0.05-0.001 \mathrm{~mm}$ ) for the texture of soils. They range from $39-40$ to $55-78 \%$ in the upper one-meter layer and from $40-49$ to $62-67 \%$ in the lower two-meter layer, and even in sandy soils with a relatively light mechanical composition, the amount of large dust particles height is observed. The results of chemical analysis of groundwater show that groundwater is located close to the surface, depending on the relief conditions and the 
The American Journal of Agriculture and Boimedical Engineering (ISSN - 2689-1018)

Published: October 21, 2020 | Pages: 12-16

base points of the area artificial drainage networks, and their mineralization level - fluctuates in a wide range from weak mineralization to salinization.
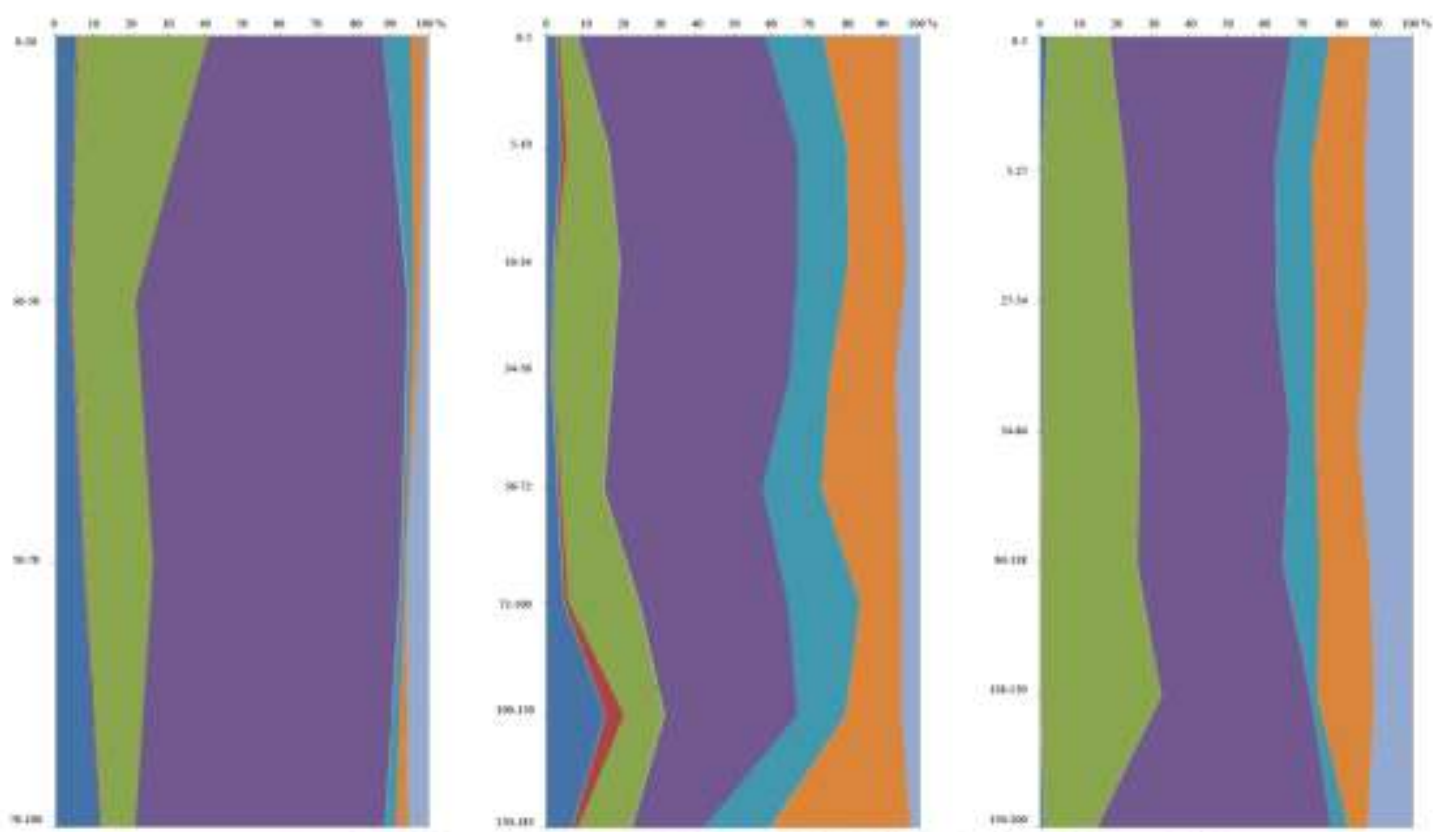

$\equiv>0,25=0,25-0,1=0,1-0,05 \equiv 0,05-0,01=0,01-0,005=0,005-0,001=<0,001$

Figure 1. Mechanical composition of virgin land soils.

In section 8 of the study, groundwater has a strong mineralization, and in most cases the amount of salts in the dry residue ranges from 7.9 to $63.2 \mathrm{~g} / \mathrm{I}$ (section 12) with a chlorine content of $0.7-15.8$; The amount of sulfates is 3.8-25.9 g/I. In the case of a high magnesium content, the presence of salts in the groundwater, as well as a high sodium content, indicates the presence of highly toxic groundwater mineralization. The total amount of toxic salts was found to be $71-72$ to $92-94 \%$ of the total water-soluble salts.

As a result of the analysis, it was found that the mechanical composition of the studied irrigated soils is very diverse, mainly related to the types of light, medium and heavy sands. In some places, there is a change in the texture, which is typical for soils with an alluvial genesis.

In the mechanical composition of irrigated sierozem soils, the amount of particles of different sizes fluctuates over a wide range: including - coarse-grained sand (>0.25 mm) from 1.6 to $3.0 \%$; small sand (0.1-0.05) 4.1 to 19.4\%; coarse dust (0.05-0.01) from 12.3 to 33.7\%; average dust (0.01-0.005) from 9.8 to 46.5\%; fine dust (0.005-0.001) ranged from 20.8 to $52.5 \%$. From this point of view, the state of diversity is also characteristic of particles il $(<0.001)$, and its content ranges from 1.3 to $18.5 \%$. The amount of physical sludge (<0.01 $\mathrm{mm}$ ) fluctuates between 53.6 and $81.6 \%$ in the described soils. 
According to the mechanical composition of irrigated meadow-sierozem soils (sections 17, 18 ), it consists mainly of medium sands, there are heavy and light sands, lithological section has a sharply layered character.

In the mechanical composition of irrigated meadow-sierozem soils, the amount of particles of different sizes fluctuates over a wide range: including - coarse sand $(>0.25 \mathrm{~mm})$ from 0.4 to $8.4 \%$; average sand (0.25-0.1mm) from 0.1 to $2.1 \%$; fine sand $(0.1-0.05 \mathrm{~mm})$ from 2.7 to $58.9 \%$; coarse dust $(0.05-0.01 \mathrm{~mm}) 11$ to $62.7 \%$; average dust $(0.01-0.005 \mathrm{~mm})$ from 1.6
Variety in this form is also a characteristic feature of the particle size $(<0.001)$, and its amount varies from 0.9 to $19.5 \%$. The amount of physical sludge $(<0.01 \mathrm{~mm})$ in the described soils varies from 5.4 to $78.9 \%$. One of the peculiarities of irrigated sierozem-meadow soils (section 16) is that the content of fine sand fractions in the relatively deep soil horizons is significantly higher, and the amount of these fractions $(0.1-0.05 \mathrm{~mm})$ ranges from 1.1 to 58 , It was found to have oscillations in the range of up to $9 \%$. The displacement of the mechanical composition along the soil section occurs gradually from heavy to light sand, or vice
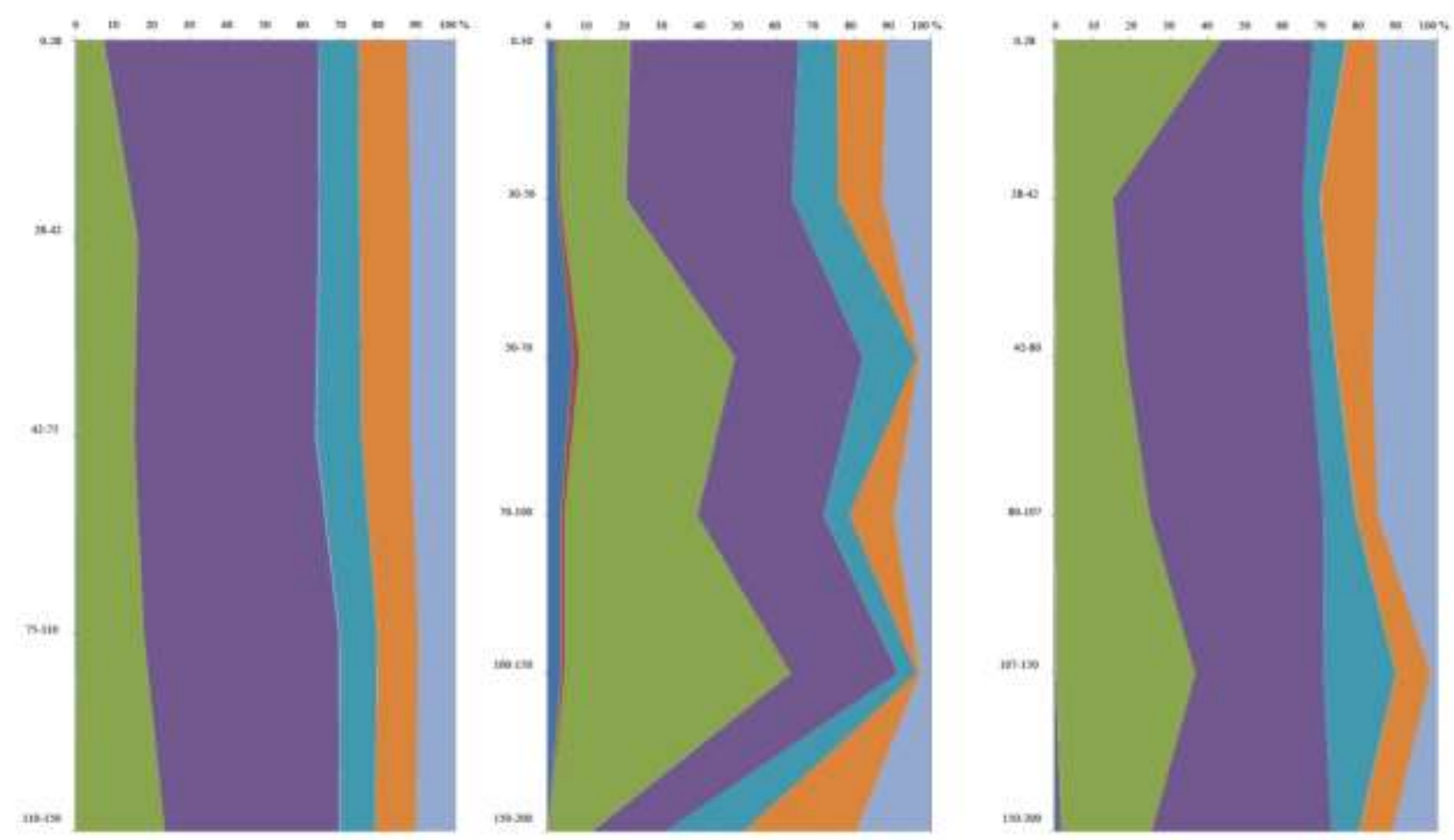

플 $>0,25=0,25-0,1=0,1-0,05$

to $39.5 \%$; fine dust $(0.005-0.001 \mathrm{~mm})$ ranges

versa.

from 0.2 to $39.2 \%$.

Figure 2. Mechanical composition of irrigated soils 
Irrigated meadow soils (sections 13,14) and swamp-meadow soils (sections 15) also differ in their mechanical composition. In the composition of meadow and swamp-meadow soils there is an increase in the amount of fine sand (11 to 59.1\%) and coarse dust (19.3 to 61.8\%) fractions.

In the general case, the multi-layered nature of the described soils and the abrupt change in the mechanical composition along the soil cross-section are their characteristic features. In some places, the clayey mechanical composition is replaced by sandy layers, while the sandy layers are replaced by clayey layers, the sharp fluctuations of the composition of mechanical fractions in this form are characterized by changes in the lithological structure of soils and, at the same time, various changes. It is also characterized by a high content of sand fractions and coarse dust in the studied soils.

\section{CONCLUSION}

In terms of the amount of coarse dust and fine sand fraction in the mechanical composition of the studied soils, the leading one, mainly consisting of medium, heavy and light sands, sometimes from lightening to loose, depending on the physical properties, mainly the mechanical composition of soils, the amount of organic matter. In all studied soils, the optimal values of specific gravity and volumetric gravity corresponded to layers with a high humus and medium texture.

\section{REFERENCES}

1. Axmedov A.U., Kamilov O.K., Ruzmetov M.I. - Aktual'nie problemi melioratsii zasolennix pochv aridnoy zoni. $\mathrm{V}$ kn.: Problemi genezisa, plodorodiya, melioratsii, ekologii pochv, otsenka zemel 'nix resursov. Alma -Ata, Kazakstan, 2002. S. 94-102.

2. 2 .

Axmedov A.U., Abdullaev S.A., Parpiev G.T. Sirdaryo va Jizzax viloyatlarining sug'oriladigan tuproqlari. Monografiya. Tashkent. Fan nashryoti, 2005. B. 122-157.

3. Gafurova L., Yamnova I., Kuziev R., Arabov S., Axmedov A., Murodova Z., Djalilova G., Parpiev G. Pochvenno - meliorativnoe sostoyanie gipsonosnix pochv podgornoy Golodnostepskoy ravnini. J.: «Vestnik agrarnoy nauki Uzbekistan», №2, T., 2008. S. 54-61.

4. Kamilov O.K. - Ob izmenenii meliorativnogo sostoyaniya pochv $\mathrm{v}$ novoy zone osvoeniya. V kn.: Genezis, geografiya i melioratsiya pochv Uzbekistana. Tr. NII pochvoved., t. VIII, T., 1972. S. 210-234.

5. Kamilov O.K. - Melioratsiya zasolennix pochv Uzbekistana na primere Golodnoy stepi. Avtoref. na sois. uch. st. dokt. s/x., M.,1982. $87 \mathrm{~s}$.

6. Kovda V.A. Problemi opustinivaniya i zasoleniya pochv aridnix regionov mira. M.: Nauka. 2008. $415 \mathrm{~s}$.

7. Kuziev R.K. Sektimenko V,YE . Pochvi Uzbekistana.-Tash., 2010. $351 \mathrm{~s}$.

8. Minashina N.G., Shishov L.L. Gipsonosnie pochvi: rasprostranenie, genezis, klassifikatsiya. J.: Pochvovedenie. 2002.№ 3. S.273-281.

9. Pankova YE.I, Gerasimova M.I. Pustinnie pochvi: svoystva, pochvoobrazovatel'nie protsessi, klassifikatsiya // Aridnie ekosistemi. T. 18. №2 (51). 2012. S. 5-16.

10. Umarov M.M. Fizicheskie svoystva pochv rayonov novogo i per-spektivnogo orosheniya Uzbekskoy SSR. -Tashkent: Fan, 1974 . 278 s. 